\title{
Studi Persepsi Masyarakat terhadap Tingkat Keberlanjutan Wilayah Pesisir Kecamatan Sarang
}

\author{
Nikken Adita Arifiani ${ }^{1}$ \\ Departemen Perencanaan Wilayah dan Kota \\ Universitas Diponegoro, Semarang, Indonesia \\ Mussadun \\ Departemen Perencanaan Wilayah dan Kota \\ Universitas Diponegoro, Semarang, Indonesia
}

Artikel Masuk : 10 Oktober 2016

Artikel Diterima : 22 November 2016

Tersedia Online : 30 Desember 2016

\begin{abstract}
Abstrak: Dinamika pembangunan di wilayah pesisir berdampak terhadap lingkungan, seperti penurunan kualitas lingkungan, abrasi pantai, banjir rob, dan kekumuhan. Penelitian bertujuan untuk mengetahui persepsi masyarakat terhadap keberlanjutan wilayah pesisir di Kecamatan Sarang yang didasarkan pada indikator pembangunan berkelanjutan dilihat dari aspek sosial, ekonomi dan lingkungan. Penelitian menggunakan pendekatan analisis kuantitatif dengan teknik analisis skoring didukung dengan deskriptif kualitatif kondisi wilayah untuk mengetahui tingkat keberlanjutan wilayah pesisir. Besaran tingkat keberlanjutan wilayah pesisir Kecamatan Sarang dibagi menjadi tiga kriteria yaitu tinggi, sedang dan rendah. Hasil analisis menunjukkan bahwa tingkat keberlanjutan wilayah pesisir Kecamatan Sarang adalah dalam skala sedang, baik dari aspek sosial, ekonomi, maupun lingkungan. Skala sedang menunjukkan bahwa pembangunan dan pemanfaatan sumber daya yang terjadi di wilayah pesisir Kecamatan Sarang telah dapat meningkatkan kesejahteraan masyarakat dan masih dapat ditolerir dari sisi lingkungan. Untuk itu, masyarakat didorong agar memiliki kepekaan terhadap kelestarian lingkungan guna menjami keberlanjutan wilayah pesisir di masa mendatang.
\end{abstract}

Kata Kunci: persepsi masyarakat, tingkat keberlanjutan, wilayah pesisir

\begin{abstract}
The dynamics of coastal area developments has impacted on the coastal environment including environmental degradation, coastal erosion, tidal flood, and slum area. This study aims to determine public perception of the sustainability of coastal areas in Sarang Sub-district regarding sustainable development indicators which cover social, economic, and environmental aspects. The study used quantitative approach method with scoring and descriptive qualitative analyses in determining the levels of sustainability in Sarang Subdistrict. It was divided into three criteria, i.e. high, medium, and low levels. The study highlighted that the level of sustainability in Sarang Sub-district coastal area was at a medium level for all aspects. The medium scale showed that the development and resource utilization occurred could improve the social welfare and be tolerated in terms of the environment. However, the low awareness on the environment cleanliness still needs more
\end{abstract}

\footnotetext{
Korespondensi Penulis: Departemen Perencanaan Wilayah dan Kota, Universitas Diponegoro, Semarang, Indonesia Email: nikkenadita@gmail.com
} 
attention to minimizing the environmental degradation Sarang Sub-district coastal area. Therefore, the local community is encouraged to have a greater awareness for ensuring its sustainability in the future.

Keywords: community perception, level of sustainability, coastal area

\section{Pendahuluan}

Wilayah pesisir adalah suatu wilayah peralihan (interface area) antara ekosistem daratan dan laut (Effendy, 2009). Hampir seluruh bagian garis pantai di Indonesia memiliki potensi untuk dikembangkan mencakup potensi perikanan, pariwisata, perkebunan, dan potensi lainnya (Basri, 2013). Selain memiliki potensi yang beragam, wilayah pesisir juga rentan terhadap bencana, seperti abrasi dan banjir rob. Fokus kegiatan pembangunan pada aspek ekonomi membuat masyarakat kurang mampu untuk mengelola sumber daya yang ada secara berkelanjutan. Pesatnya pembangunan di wilayah pesisir menyebabkan meningkatnya tekanan terhadap ekosistem sumber daya pesisir (Tuwo, 2011). Permasalahan yang terjadi di wilayah pesisir salah satunya disebabkan oleh penurunan kualitas lingkungan pesisir karena pemanfaatan sumber daya wilayah pesisir yang tidak memperhatikan prinsip-prinsip ekologi yang kemudian dapat menyebabkan kerusakan ekosistem yang ada di wilayah pesisir. Masalah lain yang ada di wilayah pesisir adalah pencemaran, over-eksploitasi, dan abrasi pantai (Rokhmin \& Ginting, 2013). Serupa dengan McGranahan, Balk, dan Anderson (2007) yang juga mengungkapkan bahwa kawasan pesisir menjadi lokasi utama untuk bertempat tinggal. Hal ini berimplikasi pada kondisi ekosistem kepesisiran dan menyebabkan kerawanan bencana di wilayah pesisir. Untuk itu, dapat dikatakan bahwa kawasan pesisir rentan terhadap bencana akibat dampak perubahan iklim karena ada keterkaitan antara perilaku manusia dengan kondisi lingkungan (Kumar, Mahendra, Nayak, Radhakrishnan, \& Sahu, 2010; Sales Jr., 2009; Torresan, Critto, Valle, Harvey, \& Marcomini, 2008).

Kecamatan Sarang tidak terlepas dari permasalahan lingkungan fisik, yaitu abrasi dan banjir rob. Bencana yang rentan terjadi di wilayah pesisir Kecamatan Sarang telah ada sejak dahulu dan terus terjadi hingga saat ini (Suhadi, 2009). Kecamatan Sarang juga terancam oleh degradasi lingkungan karena minimnya tumbuhan mangrove di pesisir serta rendahnya kesadaran masyarakat untuk menjaga kebersihan lingkungan di wilayah pesisir Sarang. Bagi lingkungan pesisir, keberadaan mangrove sangat penting dalam ekosistem pesisir. Keberadaan mangrove dapat menyumbangkan bahan organik bagi perairan sekitarnya. Perakaran yang kokoh dari mangrove memiliki kemampuan untuk meredam pengaruh gelombang, menahan lumpur, dan melindungi pantai dari erosi, gelombang pasang, dan angin topan (Auliyani, Hendrarto, \& Kismartani, 2013). Namun demikian, wilayah pesisir di Kecamatan Sarang dihadapkan pada masalah tidak tersedianya lahan di pinggir pantai untuk menanam mangrove karena sudah dipadati oleh permukiman penduduk menyebabkan sulitnya rehabilitasi ekosistem mangrove di sepanjang pantai Kecamatan Sarang (Suhadi, 2009).

Masyarakat merupakan aktor utama dalam aktivitas pembangunan. Ini dikarenakan pembangunan dilakukan oleh masyarakat dan hasil dari pembangunan juga untuk masyarakat. Pembangunan yang berkualitas dan berkelanjutan adalah pembangunan yang mengutamakan masyarakat. Masyarakat adalah sumber daya yang sangat penting karena masyarakat mampu mengatur, menjaga, mengolah, dan mengelola sumber daya dan lingkungannya sehingga dapat memenuhi kebutuhannya. Peningkatan kesadaran masyarakat dalam pengelolaan sumber daya sangat penting demi keberlanjutan suatu wilayah (Ayunita \& Hapsari, 2012). Serupa dengan Aheto et al. (2016) bahwa masyarakat 
berperan penting dalam manajemen kawasan pesisir dan bertanggung jawab terhadap keberlanjutan lingkungan karena terdapat keterkaitan erat antara perilaku manusia dengan lingkungan. Namun demikian, Ostrom (2009) mengungkapkan bahwa masyarakat tidak bisa dengan sendirinya memelihara lingkungan dan sumber daya yang dimiliki tanpa dukungan pemerintah. Kebijakan pemerintah ada yang bersifat merusak sumber daya atau mendukung tercapainya keberlanjutan. Oleh karena itu, untuk mencapai pembangunan yang berkualitas dan berkelanjutan pada kawasan pesisir, diperlukan suatu kebijakan yang tepat untuk mengatur keseimbangan pembangunan pada aspek sosial, ekonomi dan lingkungan. Di dalamnya diperlukan kolaborasi antara pembuat kebijakan, masyarakat, akademisi, dan stakeholder lain untuk mencapai kondisi sosial-ekologi yang berkelanjutan (Glaser et al., 2012).

Mengkaji besaran tingkat keberlanjutan pembangunan di wilayah pesisir Kecamatan Sarang yang diperoleh melalui pendapat masyarakat perlu dilakukan. Menggali persepsi masyarakat mengenai risiko perubahan iklim bermanfaat untuk menentukan arah kebijakan adaptasi sehingga mampu menghasilkan kebijakan yang lebih efisien (Carlton \& Jacobson, 2013). Keterlibatan masyarakat diperlukan dalam kajian tingkat keberlanjutan kawasan pesisir karena masyarakat sebagai pelaku utama pembangunan dan memiliki kontak langsung dengan lingkungan. Permasalahan penelitian yang diangkat dalam penelitian adalah mengenai persepsi masyarakat terhadap keberlanjutan wilayah pesisir Kecamatan Sarang dari aspek sosial, ekonomi dan lingkungan. Untuk itu, tujuan penelitian adalah mengetahui persepsi masyarakat terhadap keberlanjutan wilayah pesisir di Kecamatan Sarang yang didasarkan pada indikator pembangunan berkelanjutan dilihat dari aspek sosial, ekonomi dan lingkungan.

\section{Metode Penelitian}

Penelitian berlangsung selama Bulan Juni - Agustus 2016 berlokasi di kawasan pesisir Kecamatan Sarang meliputi Desa Kalipang, Sendangmulyo, Sarangmeduro, Bajingmeduro, Bajingjowo, Karangmangu, dan Temperak. Penelitian dilakukan menggunakan pendekatan kuantitatif dengan teknik analisis skoring dan analisis deskriptif. Teknik analisis skoring digunakan untuk mengetahui besaran tingkat keberlanjutan wilayah pesisir Kecamatan Sarang yang didapatkan dari hasil kuesioner yang diberikan kepada masyarakat pesisir. Sedangkan teknik analisis deskriptif digunakan untuk menggambarkan kondisi wilayah pesisir Kecamatan Sarang dari aspek sosial, ekonomi dan lingkungan sebagai pembanding antara kondisi lapangan dengan persepsi yang diberikan masyarakat terkait keberlanjutan wilayah pesisir. Deskripsi dalam penelitian difokuskan pada persepsi masyarakat terhadap keberlanjutan pesisir yang dinilai melalui indikator-indikator pembangunan berkelanjutan yang telah diuraikan dalam bentuk kuesioner serta fakta-fakta di lapangan terkait kondisi keberlanjutan pembangunan wilayah pesisir. Terdapat empat tahapan analisis dalam penelitian ini, yaitu:

a. Analisis Kondisi Sosial Masyarakat Pesisir Kecamatan Sarang

Analisis kondisi sosial masyarakat pesisir Kecamatan Sarang menggunakan data kependudukan, tingkat pendidikan, kesehatan, angkatan kerja, teknologi informasi dan komunikasi, kegiatan sosial budaya masyarakat serta sarana/prasarana di wilayah pesisir Kecamatan Sarang. Data tersebut diperoleh melalui kuesioner dan telaah dokumen untuk lebih menguatkan data yang didapat melalui kuesioner. Keluaran yang didapatkan adalah kondisi sosial budaya yang ada pada masyarakat pesisir Kecamatan Sarang.

b. Analisis Kondisi Ekonomi Wilayah Pesisir Kecamatan Sarang

Dalam analisis kondisi ekonomi wilayah pesisir Kecamatan Sarang, data-data yang digunakan meliputi pendapatan rumah tangga, akses terhadap air bersih, akses terhadap energi, sanitasi, kondisi tempat tinggal, kegiatan pariwisata, industri maritim, sumber daya 


\section{Studi Persepsi Masyarakat terhadap Tingkat Keberlanjutan Wilayah Pesisir Kecamatan Sarang}

perikanan tangkap dan budidaya, dan industri perikanan. Data-data tersebut diperoleh melalui hasil observasi dan kuesioner serta didukung dengan telaah dokumen yang kemudian diolah menggunakan analisis deskriptif kualitatif sehingga menghasilkan kondisi ekonomi wilayah pesisir di Kecamatan Sarang.

c. Analisis Kondisi Fisik Lingkungan Pesisir Kecamatan Sarang

Dalam analisis kondisi fisik lingkungan pesisir, data yang digunakan adalah data kondisi fisik lingkungan pesisir seperti keberadaan mangrove, pencemaran lingkungan pesisir, abrasi pantai, banjir rob dan pertambangan pasir pantai. Data-data ini didapatkan melalui pengamatan (observasi) dan didukung pula dengan kuesioner kepada masyarakat pesisir di Kecamatan Sarang sebagai repondennya. Data yang diperoleh tersebut dijelaskan secara deskriptif untuk mengidentifikasi kondisi fisik lingkungan pesisir Kecamatan Sarang.

d. Analisis Tingkat Keberlanjutan Wilayah Pesisir Kecamatan Sarang

Teknik analisis yang digunakan pada bagian ini adalah teknik scoring yang bertujuan untuk menilai tingkat keberlanjutan dengan memberikan nilai atau harkat pada masingmasing indikator pembangunan berkelanjutan. Skala yang digunakan dalam teknik skoring ini adalah skala likert. Skala likert digunakan untuk mengukur sikap, pendapat, dan persepsi seseorang atau sekelompok orang tentang fenomena sosial (Sugiyono, 2015). Teknik skoring menggunakan beberapa parameter penentu yang disesuaikan dengan kondisi sosial, ekonomi, dan lingkungan di daerah penelitian dengan besaran harkat yang disesuaikan dengan kontribusi relatif dari peubah tersebut terhadap kesesuaiannya bagi keberlanjutan wilayah pesisir. Semakin tinggi kontribusi kesesuaiannya bagi keberlanjutan wilayah pesisir, maka semakin tinggi pula nilai yang telah ditentukan. Tabel 1 menampilkan indikator penilaian keberlanjutan wilayah pesisir di Kecamatan Sarang yang diadaptasi dari Rokhmin dan Ginting (2013); Kay dan Alder (2005); dan Harris (2000):

Tabel 1. Indikator Keberlanjutan Wilayah Pesisir

\begin{tabular}{ll}
\hline \multicolumn{1}{c}{ Aspek } & \multicolumn{1}{c}{ Variabel } \\
\hline \multirow{3}{*}{ Ekonomi } & Pendapatan Rumah Tangga \\
& Air Bersih \\
& Akses Terhadap Energi \\
& Sanitasi \\
& Kondisi Tempat Tinggal \\
& Pendidikan \\
& Kesehatan \\
Sosial & Angkatan Kerja \\
& Teknologi Informasi Dan Komunikasi \\
& Angkutan \\
& Bencana Alam \\
Lingkungan & Pencemaran Lingkungan \\
& Abrasi Pantai \\
\hline Sumber: Rokhmin \& Ginting, $2013 ;$ Kay \& Alder, 2005; Harris, 2000 (Diolah, 2016)
\end{tabular}

Metode skoring digunakan untuk menganalisis aspek sosial, ekonomi dan lingkungan terkait keberlanjutan wilayah pesisir. Analisis potensi sosial menggunakan data sekunder yang berupa hasil kuesioner yang kemudian dirangking berdasarkan tingkatan tertinggi hingga terendah yang kemudian diharkat sesuai dengan rangking tersebut. Begitu pula dengan aspek ekonomi dan lingkungan yang juga dirangking berdasarkan tingkatan tertinggi hingga terendah kemudian diharkat sesuai dengan rangking tersebut. Total nilai masing-masing aspek kemudian dijumlah dan dirangking sesuai dengan tingkatan keberlanjutan yang telah dibuat sehingga menghasilkan tingkat keberlanjutan wilayah pesisir Kecamatan Sarang. 
Sampel penelitian sebanyak 100 responden yang mencakup masyarakat di Kecamatan Sarang. Justifikasi pemilihan masyarakat Kecamatan Sarang sebagai responden karena masyarakat setempat mengetahui status keberlanjutan wilayah pesisir Kecamatan Sarang. Diasumsikan sampel sebanyak 1,5\% dari total keseluruhan jumlah KK di setiap desa sehingga dari 7 desa didapatkan total jumlah kuesioner sebanyak 100 responden. Tabel 2 menunjukkan jumlah persebaran kuesioner di desa pesisir Kecamatan Sarang:

Tabel 2. Persebaran Kuesioner Tiap Desa

\begin{tabular}{lc}
\hline \multicolumn{1}{c}{ Desa/ Kelurahan } & Jumlah Responden \\
\hline Kalipang & 21 \\
Sendangmulyo & 16 \\
Sarangmeduro & 14 \\
Bajingmeduro & 8 \\
Bajingjowo & 13 \\
Karangmangu & 17 \\
Temperak & 11 \\
Jumlah & $\mathbf{1 0 0}$ \\
\hline
\end{tabular}

Sumber: Analisis Penyusun, 2016

Setelah diketahui jumlah pertanyaan masing-masing desa, dilakukan skoring. Skoring untuk menentukan besaran tingkat keberlanjutan wilayah pesisir Kecamatan Sarang didapatkan melalui pembobotan hasil kuesioner dengan pemberian skor pada masingmasing butir pertanyaan di lembar kuesioner sebagaimana dijabarkan di Tabel 3.

Tabel 3. Skor Tingkat Keberlanjutan Wilayah Pesisir

\begin{tabular}{cclc}
\hline Jawaban & Skala & Kategori & Bobot \\
\hline A & 1 & Tinggi & 3 \\
B & 2 & Sedang & 2 \\
C & 3 & Rendah & 1 \\
\hline
\end{tabular}

Sumber: Analisis Penyusun, 2016

Pemberian skor dilakukan pada data kuesioner yang digunakan sebagai bahan analisis untuk mengetahui tingkat keberlanjutan wilayah pesisir Kecamatan Sarang. Jenjang skor yang digunakan pada masing-masing indikator dalam aspek sosial, ekonomi dan lingkungan adalah 1 sampai 3. Skor tersebut didasarkan pada kelas rendah, sedang dan tinggi yang dilakukan untuk mengukur keberlanjutan wilayah pesisir. Nilai yang rendah dapat dijadikan acuan untuk memberikan rekomendasi guna mencapai keberlanjutan yang baik dalam pencapaian wilayah pesisir yang berkelanjutan. Berikut adalah penjelasan pemberian skor yang diadaptasi dari penelitian Ridwan \& Setiawan (2013):

- Pemberian skor untuk kategori tinggi adalah 3 apabila indikator tersebut telah memenuhi kriteria atau ketentuan yang seharusnya telah ditetapkan melalui pilihan yang telah diberikan pada jawaban kuesioner.

- Skor untuk kategori sedang adalah 2. Ini menunjukkan bahwa pilihan jawaban yang diberikan masih dapat memenuhi kriteria.

- Kategori rendah diberikan skor 1, yaitu menunjukkan jawaban yang diberikan responden tidak memenuhi kriteria yang ditetapkan.

Pembobotan diatas digunakan untuk mengetahui besaran tingkat keberlanjutan wilayah pesisir Kecamatan Sarang dengan kriteria sebagai berikut (Coastal \& Marine Union (EUCC), 2012): 


\section{Studi Persepsi Masyarakat terhadap Tingkat Keberlanjutan Wilayah Pesisir Kecamatan Sarang}

- Kriteria keberlanjutan tinggi, yaitu pembangunan di wilayah pesisir telah berhasil meningkatkan kesejahteraan masyarakat dan selaras dengan kelestarian lingkungan pesisir sehingga pembangunan yang terjadi tidak berdampak buruk bagi lingkungan.

- Kriteria keberlanjutan sedang, menunjukkan bahwa pembangunan yang terjadi di wilayah pesisir telah dapat meningkatkan kesejahteraan masyarakat dan masih dapat ditolerir dari sisi lingkungan meskipun masih diperlukan perbaikan ke depan demi menyelaraskan kegiatan pembangunan dengan kelestarian pesisir.

- Kriteria keberlanjutan rendah, yaitu pembangunan yang terjadi di wilayah pesisir belum dapat menyejahterakan masyarakat dan berdampak buruk terhadap lingkungan pesisir sehingga timbul permasalahan lingkungan akibat dari pembangunan yang ada.

Rentang nilai pada Tabel 4 didapatkan dari hasil total pertanyaan kuesioner masingmasing desa dikalikan dengan bobot sehingga didapatkan rentang nilai untuk menilai tingkat keberlanjutan masing-masing desa di wilayah pesisir Kecamatan Sarang.

Tabel 4. Kategori Nilai Keberlanjutan Tiap Desa

\begin{tabular}{lccc}
\hline \multirow{1}{*}{ Desa } & \multicolumn{3}{c}{ Rentang Nilai } \\
\cline { 2 - 4 } & Tinggi & Sedang & Rendah \\
\hline Kalipang & $2.255-2.898$ & $1.611-2.254$ & $966-1.610$ \\
Sendangmulyo & $1.719-2.208$ & $1.228-1.718$ & $736-1.227$ \\
Sarangmeduro & $1.503-1.932$ & $1.074-1.502$ & $644-1.073$ \\
Bajingmeduro & $859-1.104$ & $614-858$ & $368-613$ \\
Bajingjowo & $1.397-1.794$ & $998-1396$ & $598-997$ \\
Karangmangu & $1.825-2.346$ & $1.304-1.824$ & $782-1.303$ \\
Temperak & $1.181-1.518$ & $844-1.180$ & $506-843$ \\
\hline
\end{tabular}

Sumber: Analisis Penyusun, 2016

\section{Hasil dan Pembahasan}

Hasil dari penelitian persepsi masyarakat terhadap keberlanjutan wilayah pesisir Kecamatan Sarang terdiri dari analisis kondisi sosial masyarakat pesisir Kecamatan Sarang, analisis kondisi ekonomi wilayah pesisir Kecamatan Sarang, analisis kondisi fisik lingkungan pesisir Kecamatan Sarang, serta analisis tingkat keberlanjutan wilayah pesisir Kecamatan Sarang.

\section{Analisis Kondisi Sosial Masyarakat Pesisir Kecamatan Sarang}

Sumber daya pesisir yang paling dikenal oleh masyarakat adalah sumber daya perikanan dan sering dimanfaatkan sebagai sumber pangan. Bagi masyarakat pesisir, ikan merupakan hal yang selalu ada di kehidupan sehari-hari mereka baik untuk dikonsumsi maupun dijual. Masyarakat pesisir Kecamatan Sarang memanfaatkan sumber daya perikanan dalam kegiatan sehari-hari seperti dikonsumsi maupun dijual kembali ataupun diolah menjadi produk perikanan. Sebagian besar masyarakat yang berprofesi sebagai nelayan dan pedagang ikan memanfaatkannya untuk mencukupi kebutuhan sehari-hari.

Jumlah penduduk yang bekerja di bidang perikanan, baik sebagai nelayan maupun pedagang ikan, berjumlah 4.135 jiwa. Penduduk Desa Karangmangu yang bekerja di bidang perikanan merupakan yang paling banyak diantara desa pesisir lainnya dengan jumlah 1.093 jiwa. Namun, apabila dibandingkan dengan jumlah penduduk desa, Desa Sarangmeduro mempunyai jumlah penduduk terbanyak untuk penduduk yang bekerja di bidang perikanan, yaitu sekitar 23,5\% dari total jumlah penduduk Desa Sarangmeduro. Hal ini dikarenakan Desa Sarangmeduro berada tepat di tepi pantai dan tempat pelelangan ikan berada di desa ini sehingga masyarakat banyak yang bekerja sebagai nelayan dan pedagang 
ikan. Di samping itu, Desa Sarangmeduro juga merupakan salah satu kampung nelayan di Kecamatan Sarang karena potensi yang dimiliki tersebut.

Kaum perempuan di wilayah pesisir Kecamatan Sarang banyak yang bekerja sebagai pedagang ikan dan pembuat ikan asap maupun buruh pada industri pengasinan ikan. Banyak dijumpai industri pengolah perikanan menjadi ikan asap, ikan asin dan terasi. Industri tersebut masih skala rumah tangga dengan jumlah pekerja dibawah 20 orang. Industri perikanan skala rumah tangga paling banyak ditemui di Desa Karangmangu dan Temperak. Selain industri skala rumah tangga, terdapat pula industri pengolah perikanan skala besar di Desa Temperak. Industri ini merupakan industri pengawetan ikan dengan cara dibekukan untuk dikirim ke luar wilayah.

\section{Analisis Kondisi Ekonomi Wilayah Pesisir Kecamatan Sarang}

Masyarakat wilayah pesisir bertumpu pada sektor perikanan dalam kegiatan perekonomian sehari-hari. Pemanfaatan sumber daya perikanan secara terus menerus harus diiringi dengan kegiatan pelestarian ekosistem supaya sumber daya yang ada masih dapat terjaga kelestariannya dan dapat dimanfaatkan untuk masa yang akan datang. Oleh karena itu, aspek ekonomi dalam pembangunan berkelanjutan sangat penting diperhatikan. Pada wilayah pesisir Kecamatan Sarang, aspek ekonomi yang dapat mendukung keberlanjutan wilayah di antaranya adalah pemanfaatan sumber daya perikanan baik perikanan tangkap maupun budidaya, kegiatan pariwisata, industri perkapalan, industri perikanan serta tambak garam.

a. Sumber daya Perikanan Tangkap dan Budidaya

Pemanfaatan sumber daya perikanan tangkap adalah dengan menangkap ikan di laut dan menjualnya ke TPI Kecamatan Sarang. Jenis ikan yang sering ditangkap nelayan adalah ikan layang, bawal hitam, kembung, selar, tembang atau jui, tongkol, tenggiri dan cumi-cumi. Ikan yang masuk ke TPI kemudian dilakukan lelang kepada para pedagang ikan yang sudah menunggu untuk kemudian dijual kembali ke pasar ataupun dibawa ke pabrik pengolah ikan yang ada di Desa Temperak dan ke industri rumah tangga pengolah hasil perikanan seperti pengeringan ikan, pengasinan ikan maupun pengasapan ikan yang banyak terdapat di wilayah pesisir. Kegiatan budidaya ikan dilakukan di tambak-tambak yang berada di wilayah pesisir. Jenis ikan yang dibudidayakan antara lain ikan bandeng, udang windu, udang vanammei dan ikan nila. Namun, ikan bandeng dan udang vanammei. Pemilihan jenis udang vanammei paling banyak dibudidayakan karena daya tahan yang lebih bagus dibandingkan dengan udang windu.

b. Kegiatan Pariwisata

Kegiatan pariwisata bahari di Kecamatan Sarang belum dilakukan secara maksimal. Potensi keindahan pantai yang ada di Desa Kalipang dan Desa Temperak hingga saat ini belum dimanfaatkan sebagai lokasi wisata. Hanya ada satu buah restoran dengan konsep bahari di Desa Kalipang yang lokasinya berada di pinggir jalur pantura dan dekat dengan pantai yang saat ini menjadi lokasi wisata bahari di Desa Kalipang yang telah dikelola dengan baik. Desa Temperak juga memiliki potensi wisata pantai pasir putih. Kondisi pantai yang sepi dan sangat mudah dijangkau dari jalur pantura juga dekat dengan perbatasan Jawa Timur membuat lokasi ini memiliki potensi besar dikembangkan sebagai tempat wisata. Namun sayangnya karena lokasi tersebut bukan merupakan lokasi wisata resmi, membuat kondisinya tidak terawat dengan baik. Hal ini ditunjukkan dengan masih adanya sampah yang berserakan di pantai yang membuat warga enggan untuk berkunjung menikmati keindahan pantai pasir putih.

c. Industri Perkapalan

Sebagai pusat galangan kapal satu-satunya di Kabupaten Rembang, Kecamatan Sarang berpeluang besar dalam industri perkapalan di Jawa Tengah. Sebanyak 18 usaha galangan kapal dengan rata-rata jumlah pekerja dalam setiap galangan sebanyak 10 hingga 20 orang 
membuat usaha ini berkontribusi dalam membuka lapangan kerja bagi warga sekitar karena selama ini pekerja galangan kapal berasal dari dalam Kecamatan Sarang. Namun demikian, mereka dibekali keterampilan membuat kapal mulai dari perahu kecil hingga kapal dengan bobot mati mencapai 50 ton. Sebagian besar pekerja mendapatkan keterampilan tersebut secara otodidak. Para pekerja yang ada di galangan kapal terdiri dari berbagai usia, mulai dari usia 18 tahun hingga 60 tahun keatas.

d. Industri Perikanan

Di wilayah pesisir Kecamatan Sarang banyak dijumpai industri pengolah hasil perikanan baik dalam skala rumah tangga maupun skala pabrik. Industri rumah tangga berada di sekitar pesisir pantai mulai dari Desa Kalipang hingga Desa Temperak namun paling banyak adalah di Desa Sarangmeduro, Bajingmeduro, Karangmangu dan Desa Temperak. Industri tersebut mengolah ikan yang didapat langsung dari nelayan menjadi ikan asin maupun ikan asap. Pada pengolahan ikan asin, industri biasanya memiliki jumlah pekerja yang banyak, sekitar 10 sampai 20 orang yang terdiri dari ibu rumah tangga sekitar lokasi industri dan juga dibantu oleh beberapa buruh laki-laki untuk mengangkat ikan.

e. Tambak Garam

Kabupaten Rembang merupakan daerah penghasil garam terbesar di Jawa Tengah dengan luas total 795,36 hektar dan tersebar di Kecamatan Kaliori, Rembang, Lasem, Sluke dan Kecamatan Sarang. Oleh karena itu, selain memiliki tambak ikan dan udang, di Kecamatan Sarang juga terdapat tambak garam dengan luas total mencapai 64,60 hektar. Lahan tambak garam tersebut tersebar di empat desa, yakni Desa Kalipang, Desa Sendangmulyo, Desa Karangmangu dan Desa Temperak. Lahan tambak garam terluas berada di Desa Sendangmulyo seluas 26,60 hektar. Pemilik tambak garam di Kecamatan Sarang seluruhnya berjumlah 53 orang. Sedangkan pekerja tambak sebanyak 149 orang. Produksi garam di Kecamatan Sarang mencapai 3.281 ton pada tahun 2013. Keberhasilan produksi garam ditentukan oleh faktor cuaca dan juga salinitas air laut yang digunakan sebagai bahan baku pembuatan garam. Lokasi tambak berada di dekat laut untuk memudahkan pengambilan air laut menuju tambak. Hasil produksi garam ini selanjutnya dikirim ke pabrik garam yang berada di Jawa Timur untuk kemudian dikemas dan dipasarkan sebagai garam dapur.

\section{Analisis Kondisi Fisik Lingkungan Pesisir Kecamatan Sarang}

Aspek fisik lingkungan Kecamatan Sarang meliputi kondisi pesisir, yaitu dari keberadaan hutan mangrove, kegiatan pertambangan pasir pantai, pencemaran lingkungan, bencana abrasi dan rob. Dengan mengetahui kondisi lahan atau daerah pesisir yang dapat dikembangkan maka prospek untuk berkembang dapat diidentifikasi. Selain itu juga meliputi upaya pengurangan dan pencegahan terhadap polusi, pengelolaan limbah, serta konservasi atau preservasi sumber daya alam.

\section{a. Mangrove}

Keberadaan ekosistem mangrove di Kabupaten Rembang mengalami penurunan drastis diakibatkan oleh aktivitas manusia di pinggir pantai seiring dengan bertambahnya jumlah penduduk yang tinggal di kawasan pesisir. Menurut Setyawan dan Winarno (dalam Auliyani et al., 2013) aktivitas pertambakan, penebangan mangrove, reklamasi dan sedimentasi, serta pencemaran lingkungan merupakan beberapa faktor penyumbang terbesar kerusakan ekosistem mangrove di Kabupaten Rembang. Penurunan jumlah mangrove juga menjadi penyebab abrasi yang memperparah kondisi pesisir di Kabupaten Rembang. Ekosistem mangrove di pesisir Kabupaten Rembang tidak hanya terbentuk di kawasan muara sungai namun terutama terbentuk pada lokasi-lokasi tertentu yang terlindung dari gelombang laut, yakni tempat sedimen dari sungai dan laut terendapkan dan membentuk tidal flat. Oleh karena itu, mangrove di Kabupaten Rembang terpusat di 
sebelah barat dari Gunung Lasem meliputi Kecamatan Kaliori, Rembang dan Lasem (Auliyani et al., 2013).

Keadaan geografis inilah yang menyebabkan di Kecamatan Sarang jarang ditemui ekosistem mangrove di wilayah pesisir. Selain itu, pertumbuhan penduduk menyebabkan lingkungan pesisir menjadi padat dengan permukiman. Tumbuhan mangrove hanya dijumpai pada muara sungai yang ada di Desa Kalipang dan Desa Temperak, mengingat di dua desa ini terdapat muara sungai yang cukup lebar yang menjadi tempat tumbuhnya tanaman mangrove karena terlindung dari hempasan gelombang laut dan menjadi tempat sedimen dari sungai dan laut yang terendapkan. Sementara itu, pada desa pesisir lainnya tidak ada tumbuhan mangrove di sepanjang pantainya karena kondisi pantai di Kecamatan Sarang bukan merupakan tidal flat sehingga tidak cocok untuk ditanami tanaman mangrove. Padahal, menurut Sutrisno (2015) bahwa mangrove yang dapat dikembangkan dengan baik oleh masyarakat pesisir dapat meningkatkan kondisi ekonomi masyarakat.

b. Pertambangan Pasir Pantai

Sulitnya mencari pasir hitam dan harga yang mahal membuat warga pesisir Kecamatan Sarang memilih untuk menggunakan pasir pantai sebagai bahan bangunan yaitu sebagai bahan dasar pembuatan batako dan campuran pondasi bangunan. Oleh karena itu, di wilayah pesisir marak terjadi penambangan pasir pantai ilegal. Penambangan pasir pantai paling parah terjadi di Desa Temperak, karena lokasi pantai yang berdekatan dengan jalan utama pantura sehingga memudahkan untuk mengangkut hasil tambang pasir pantai tersebut. Para penambang pasir menggunakan alat tradisional untuk menggali pasir yang kemudian diangkut dengan kendaraan roda tiga untuk dijual. Penambangan pasir kuarsa di wilayah pesisir ini bersifat ilegal, karena membahayakan lingkungan pesisir dan menyebabkan abrasi pantai.

c. Abrasi dan Banjir Rob

Abrasi merupakan masalah yang umum terjadi di wilayah pesisir Indonesia. Abrasi pantai juga menjadi permasalahan utama yang melanda wilayah pesisir Kecamatan Sarang. Dalam kurun waktu tahun 2003 hingga tahun 2008, wilayah tepian pantai di Kecamatan Sarang telah mengalami mundur garis pantai sejauh 4,17 meter dan pada tahun 2008 hingga tahun 2014 mengalami mundur garis pantai sejauh 4,43 meter. Mundurnya garis pantai ini telah menyebabkan sebagian permukiman penduduk hilang akibat tergerus abrasi. Masalah abrasi tersebut masih terjadi hingga saat ini dan paling parah terjadi di Desa Temperak. Perubahan fungsi lahan pesisir yang seharusnya merupakan kawasan sempadan pantai menjadi kawasan permukiman membuat kawasan disepanjang pesisir Kecamatan Sarang menjadi rawan abrasi. Desa Sarangmeduro, Bajingmeduro, Karangmangu, dan Temperak merupakan desa pesisir dengan permukiman yang sangat padat. Rata-rata jarak antara permukiman warga dengan bibir pantai kurang dari 10 meter. Kondisi ini sangat rawan dengan terjadinya gelombang pasang yang dapat menggerus permukiman warga.

Masuknya air laut menuju permukiman warga pesisir Kecamatan Sarang terjadi ketika gelombang laut sedang tinggi. Lokasi permukiman yang berada dekat dengan bibir pantai, membuat air laut mudah masuk dan menyebabkan banjir rob. Tidak ada saluran drainase juga membuat banjir rob semakin parah. Banjir rob paling sering terjadi di lingkungan permukiman Desa Kalipang, Sarangmeduro, Bajingmeduro dan Karangmangu. Deretan perkantoran yang ada di Desa Kalipang berada tepat di tepi pantai dan hanya dibatasi oleh tanggul sebagai penahan gelombang. Tetapi ketika musim penghujan dan gelombang tinggi, air laut sering masuk ke area perkantoran sehingga mengganggu aktivitas.

d. Pengelolaan Sampah

Kebiasaan masyarakat pesisir membuang sampah ke laut sulit dihilangkan karena mereka sudah menganggap hal itu lebih mudah dan praktis tanpa mengeluarkan biaya. 
Sangat rendahnya kesadaran masyarakat dalam membuang sampah menyebabkan lingkungan pesisir menjadi kumuh. Ditambah lagi tidak adanya fasilitas pengangkutan sampah bagi desa-desa yang berada di wilayah pesisir. Untuk masyarakat yang tinggal dekat dengan laut, mereka membuang sampah langsung menuju laut. Sedangkan pada lingkungan permukiman yang agak jauh dari pantai, mereka mengolah sampahnya dengan cara dibakar atau dibuang ke lahan kosong. Hanya dua desa saja yang sudah terfasilitasi pengangkutan sampah, yaitu Desa Sendangmulyo dan Bajingjowo. Walaupun sudah tersedia bak sampah dan dilaksanakan pengangkutan sampah setiap hari di kedua desa, namun kesadaran masyarakat akan kebersihan lingkungan yang sangat rendah menyebabkan masih banyaknya sampah berserakan di sekitar jalan-jalan lingkungan.

Kondisi fisik lingkungan kawasan pesisir berkorelasi dengan aktivitas yang terjadi di dalamnya. Hal ini sesuai dengan pendapat Kumar et al. (2010), Sales Jr. (2009), dan Torresan et al. (2008) bahwa terdapat keterkaitan antara perilaku masyarakat dengan lingkungan di wilayah pesisir.

\section{Analisis Tingkat Keberlanjutan Wilayah Pesisir Kecamatan Sarang}

Analisis tingkat keberlanjutan wilayah pesisir Kecamatan Sarang dibagi berdasarkan aspek sosial, ekonomi dan lingkungan. Masing-masing aspek diukur tingkat keberlanjutannya melalui skoring hasil kuesioner yang dikerjakan masyarakat pesisir Kecamatan Sarang. Desa yang termasuk ke dalam wilayah pesisir adalah Desa Kalipang, Sedangmulyo, Sarangmeduro, Bajingmeduro, Bajingjowo, Karangmangu dan Temperak. Jumlah responden dalam kuesioner ini adalah sebanyak 100 orang yang sudah didistribusikan ke dalam tujuh desa pesisir. Dari hasil kuesioner yang telah dilakukan, tingkat keberlanjutan wilayah pesisir Kecamatan Sarang secara keseluruhan adalah dalam skala sedang. Tabel 5 menjelaskan hasil skoring tingkat keberlanjutan wilayah pesisir Kecamatan Sarang dirinci tiap desa:

Tabel 5. Tingkat Keberlanjutan Wilayah Pesisir Kecamatan Sarang

\begin{tabular}{|c|c|c|c|}
\hline Desa & Skor & $\begin{array}{c}\text { Tingkat } \\
\text { Keberlanjutan }\end{array}$ & Faktor yang Kurang dalam Keberlanjutan Wilayah \\
\hline Kalipang & 2174 & Sedang & $\begin{array}{l}\text { Sosial: } \\
\text { - Kurangnya kegiatan sosial bermasyarakat seperti } \\
\text { kegiatan karang taruna, kumpul RT, kerja bakti \& } \\
\text { siskamling. } \\
\text { - Kegiatan pemanfaatan sumber daya pesisir tidak } \\
\text { dibarengi dengan pelestarian. } \\
\text { Ekonomi: } \\
\text { - Kegiatan industri pengolahan ikan masih secara } \\
\text { tradisional. } \\
\text { - Kegiatan industri pembuatan kapal banyak yang } \\
\text { belum berizin. } \\
\text { Lingkungan: } \\
\text { - Masyarakat masih membuang sampah ke laut/tepi } \\
\text { pantai. } \\
\text { - Ekosistem mangrove sangat sedikit. } \\
\text { - Tidak ada sempadan pantai. } \\
\text { - Jarak permukiman pesisir dengan bibir pantai <10 } \\
\text { meter. }\end{array}$ \\
\hline Sendangmulyo & 1570 & Sedang & $\begin{array}{l}\text { Sosial: } \\
\text { - Kurangnya kegiatan sosial bermasyarakat seperti } \\
\text { kegiatan karang taruna, kumpul RT, kerja bakti \& } \\
\text { siskamling. }\end{array}$ \\
\hline
\end{tabular}




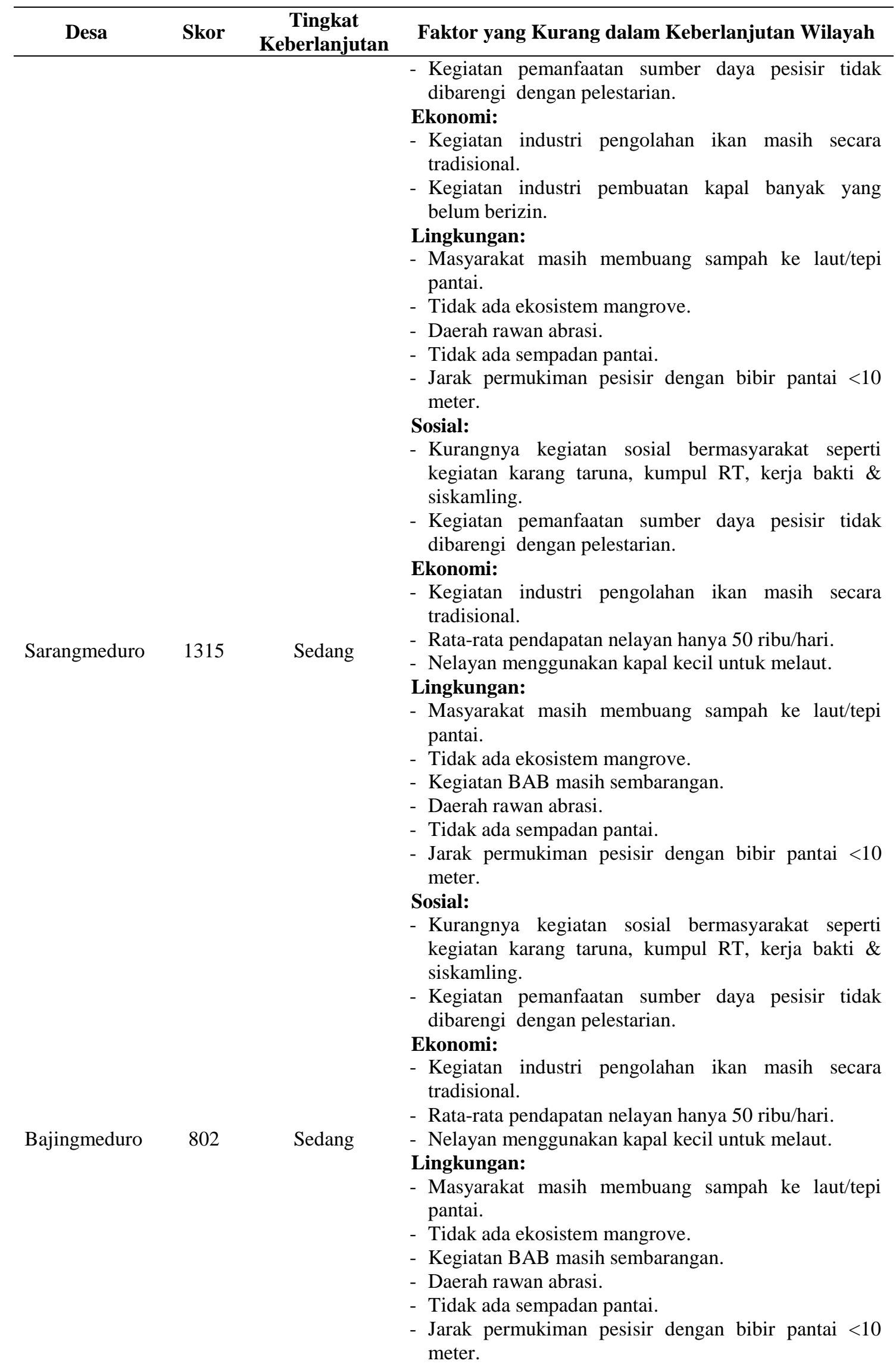




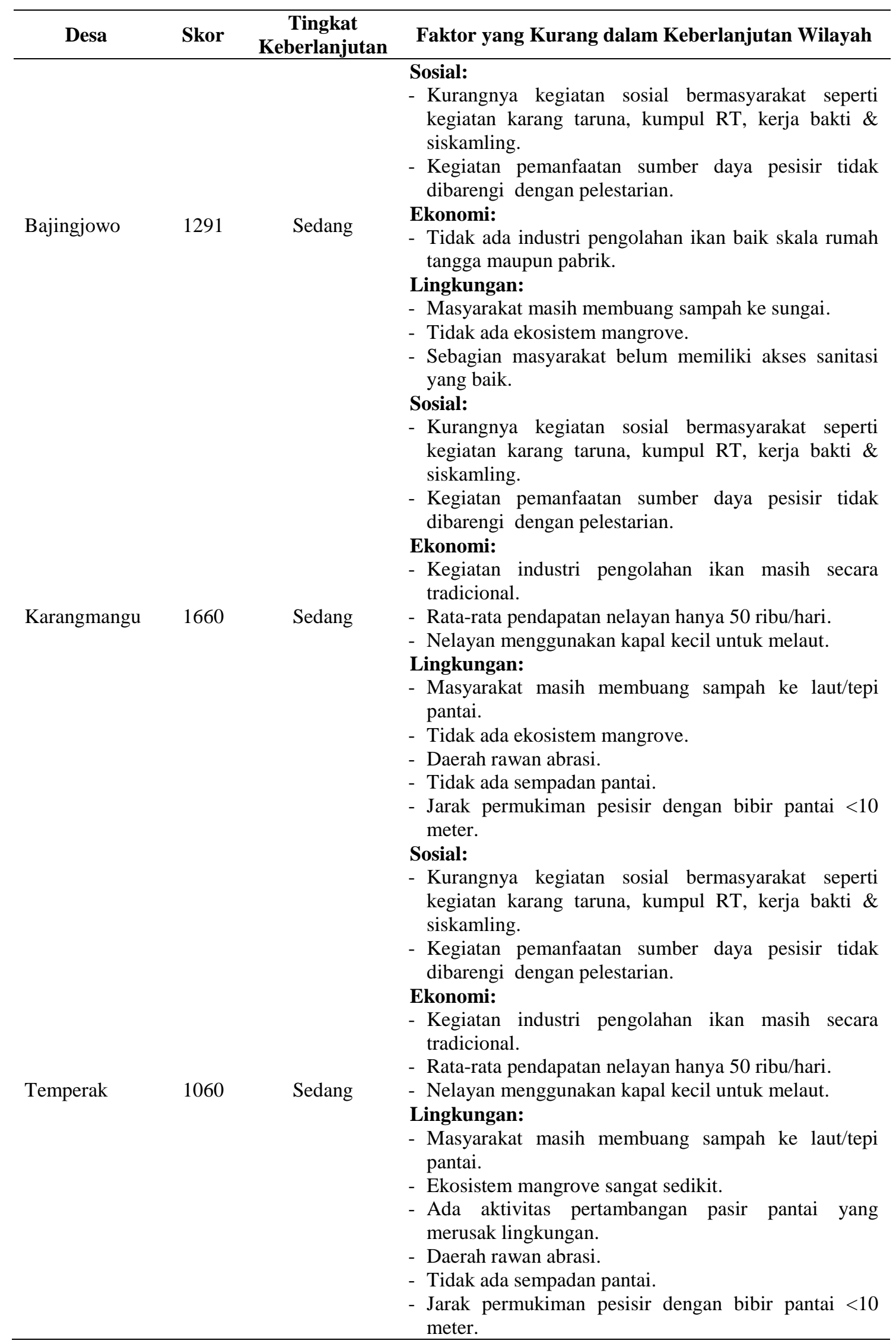

Sumber: Analisis Penyusun, 2016 
Pada masing-masing aspek keberlanjutan meliputi aspek sosial, ekonomi dan lingkungan, terdapat beragam tingkat keberlanjutan di setiap desa. Pada aspek sosial, seluruh desa berada pada tingkat sedang berkelanjutan. Pada aspek ekonomi, ada tiga desa dengan tingkat keberlanjutan yang tinggi, yaitu Desa Kalipang, Bajingmeduro dan Karangmangu dan empat desa lainnya mendapat kategori sedang berkelanjutan. Sedangkan pada aspek lingkungan, seluruh desa di wilayah pesisir masuk kedalam kategori sedang berkelanjutan. Tabel 6 menunjukkan tingkat keberlanjutan di wilayah pesisir Kecamatan Sarang masing-masing aspek:

Tabel 6. Tingkat Keberlanjutan Wilayah Pesisir Kecamatan Sarang

\begin{tabular}{lcccccc}
\hline \multirow{2}{*}{ Desa } & \multicolumn{2}{c}{ Sosial } & \multicolumn{2}{c}{ Ekonomi } & \multicolumn{2}{c}{ Lingkungan } \\
\cline { 2 - 7 } & Skor & Status & Skor & Status & Skor & Status \\
\hline Kalipang & 942 & Sedang & 761 & Tinggi & 471 & Sedang \\
Sendangmulyo & 683 & Sedang & 560 & Sedang & 327 & Sedang \\
Sarangmeduro & 564 & Sedang & 480 & Sedang & 271 & Sedang \\
Bajingmeduro & 348 & Sedang & 301 & Tinggi & 153 & Sedang \\
Bajingjowo & 562 & Sedang & 448 & Sedang & 281 & Sedang \\
Karangmangu & 707 & Sedang & 620 & Tinggi & 333 & Sedang \\
Temperak & 461 & Sedang & 374 & Sedang & 225 & Sedang \\
\hline
\end{tabular}

Sumber: Analisis Penyusun, 2016

Pada aspek sosial, seluruh desa berada pada skala sedang. Faktor yang menghambat wilayah pesisir Kecamatan Sarang dalam keberlanjutan aspek sosial adalah kegiatan sosial masyarakat yang belum maksimal dilaksanakan serta faktor pendidikan yang rendah sehingga pengetahuan masyarakat terhadap pemanfaatan sumber daya pesisir untuk meningkatkan perekonomian juga masih rendah. Hal tersebut mengakibatkan kurangnya perhatian masyarakat terhadap kelestarian lingkungan pesisir. Perilaku buruk masyarakat dalam membuang sampah menjadi penyebab penurunan kualitas lingkungan.

Pada aspek ekonomi, hanya tiga desa yang berskala tinggi dan empat desa lainnya berskala sedang. Tiga desa yang berskala tinggi adalah Desa Kalipang, Bajingmeduro dan Karangmangu. Tiga desa tersebut merupakan desa dengan pertumbuhan ekonomi yang baik dibandingkan desa lainnya. Hal ini dapat terlihat dari aktivitas ekonomi yang bergerak di desa ini yaitu ekonomi pesisir dengan banyaknya warga yang bekerja di bidang perikanan dan juga industri perikanan serta industri pembuatan kapal yang berada di Desa Kalipang.

Aspek fisik lingkungan di wilayah pesisir Kecamatan Sarang seluruhnya berskala sedang. Sangat minimnya ekosistem mangrove serta kebiasaan buruk masyarakat dalam membuang sampah menyebabkan lingkungan permukiman menjadi kumuh. Selain itu, wilayah pesisir Kecamatan Sarang yang rawan abrasi pantai juga masih perlu dilakukan penanganan untuk mencapai keberlanjutan dalam aspek lingkungan di Kecamatan Sarang.

Setelah hasil kuesioner diakumulasikan dari tiap-tiap aspek, tingkat keberlanjutan wilayah pesisir Kecamatan Sarang hasilnya dipetakan. Peta tingkat keberlanjutan wilayah pesisir Kecamatan Sarang terlihat di Gambar 1.

Hasil skoring juga menunjukkan bahwa tingkat keberlanjutan wilayah pesisir Kecamatan Sarang termasuk kategori sedang dengan skor total 9.822. Skor ini didapatkan dari total jawaban responden yang telah dikalikan dengan masing-masing bobot jawaban. Skala sedang tersebut menunjukkan bahwa pembangunan yang terjadi di wilayah pesisir Kecamatan Sarang telah dapat meningkatkan kesejahteraan masyarakat dan masih dapat 
ditolerir dari sisi lingkungan, meski harus ada perbaikan sikap dari masyarakat terkait pengelolaan sampah agar kerusakan lingkungan di wilayah pesisir dapat berkurang. Kegiatan masyarakat dalam memanfaatkan sumber daya pesisir untuk menunjang perekonomian sudah baik, terbukti dengan peningkatan kesejahteraan masyarakat yang dapat dilihat melalui kepemilikan rumah dan kategori kesejahteraan melalui data statistik. Namun masih rendahnya kesadaran masyarakat dalam menjaga kelestarian lingkungan perlu untuk ditingkatkan demi menjaga kelangsungan ekosistem pesisir.

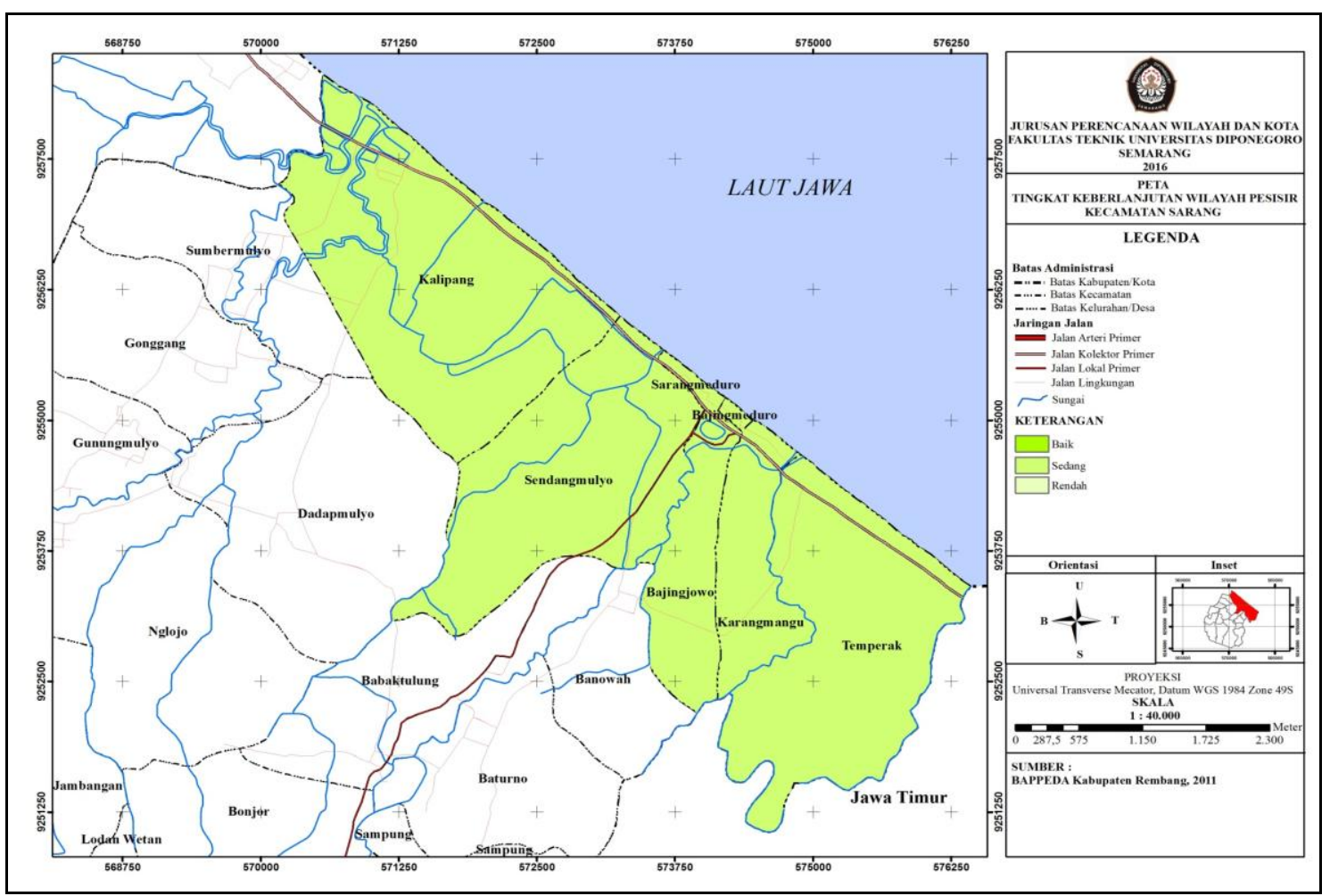

Sumber: Analisis Penyusun, 2016

Gambar 1. Peta Tingkat Keberlanjutan Wilayah Pesisir Kecamatan Sarang

\section{Kesimpulan dan Rekomendasi}

\section{Kesimpulan}

Masyarakat pesisir memiliki posisi penting dalam konteks keberlanjutan wilayah pesisir. Masyarakat pesisir merupakan penghuni wilayah yang memiliki ragam aktivitas serta perilaku dan menentukan kondisi wilayah pesisir. Untuk itu, menilai keberlanjutan wilayah pesisir berdasarkan persepsi masyarakat perlu dilakukan. Keberlanjutan wilayah pesisir Kecamatan Sarang secara keseluruhan dalam tingkat sedang dengan jumlah skor 8.844 atau $70,19 \%$ kondisi wilayah pesisirnya tergolong baik dilihat dari aspek sosial, ekonomi dan lingkungan. Masing-masing desa juga memiliki tingkat keberlanjutan skala sedang. Pada aspek sosial, seluruh desa pesisir tergolong dalam skala sedang pada tingkat keberlanjutannya. Pada aspek ekonomi, ada 3 desa yang tergolong dalam skala keberlanjutan tinggi yaitu Desa Kalipang, Bajingmeduro dan Karangmangu. Sedangkan 4 desa lainnya termasuk dalam skala sedang, yaitu Desa Sendangmulyo, Sarangmeduro, Bajingjowo, dan Temperak. Pada aspek lingkungan, seluruh desa pesisir termasuk kedalam 
skala keberlanjutan sedang. Skala sedang menunjukkan bahwa pembangunan yang terjadi di wilayah pesisir Kecamatan Sarang telah dapat meningkatkan kesejahteraan masyarakat dan masih dapat ditolerir dari sisi lingkungan.

\section{Rekomendasi}

Selama ini pemerintah hanya fokus pada sektor perikanan sebagai sektor utama penggerak perekonomian pesisir Kecamatan Sarang. Sedangkan potensi lainnya seperti pariwisata dan industri maritim belum secara optimal dimanfaatkan. Begitu pula dengan masyarakat yang selama ini hanya bergantung pada sektor perikanan baik perikanan tangkap maupun budidaya dan kurang memanfaatkan potensi lainnya. Rendahnya kesadaran masyarakat dalam menjaga kebersihan lingkungan pesisir juga menyebabkan lingkungan pesisir menjadi tercemar oleh limbah rumah tangga, dan tidak ada upaya dari pemerintah untuk menjalankan sistem pengangkutan sampah bagi masyarakat yang tinggal di wilayah pesisir sehingga menyebabkan kondisi lingkungan pesisir menjadi kumuh. Oleh karena itu, pada aspek sosial perlu meningkatkan kesadaran masyarakat mengenai pentingnya menjaga kelestarian lingkungan dalam upaya pemanfaatan sumber daya pesisir. Pada aspek ekonomi, perlu meningkatkan kesejahteraan masyarakat melalui upaya pemerintah dalam memberikan bantuan modal dan peningkatan inovasi dalam bidang pengolahan perikanan sehingga masyarakat lebih inovatif dan berdaya saing tinggi pada industri perikanan. Pada aspek lingkungan, perlu adanya peraturan tegas mengenai pembangunan permukiman yang ada di wilayah pesisir dan peraturan sempadan pantai sesuai yang tertuang pada Rencana Tata Ruang Wilayah Kabupaten Rembang tahun 2011 mengenai sempadan pantai karena hingga saat ini wilayah permukiman di pesisir sangat padat dan minim ruang terbuka hijau dan permukiman telah mendesak pantai sehingga sangat rawan terhadap abrasi dan rob.

\section{Daftar Pustaka}

Aheto, D. W., Kankam, S., Okyere, I., Mensah, E., Osman, A., Jonah, F. E., \& Mensah, J. C. (2016). Communitybased mangrove forest management: Implications for local livelihoods and coastal resource conservation along the Volta estuary catchment area of Ghana. Ocean \& Coastal Management, 127, 4354. doi:10.1016/j.ocecoaman.2016.04.006.

Auliyani, D., Hendrarto, B., \& Kismartani. (2013). Pengaruh rehabilitasi mangrove terhadap kondisi sosial ekonomi masyarakat pesisir Kabupaten Rembang. In S. P., Hadi, Purwanto, H. R. Sunoko, \& H. Purnaweni (Eds.), Optimasi Pengelolaan Sumber daya Alam dan Lingkungan dalam Mewujudkan Pembangunan Berkelanjutan (pp. 317-321). Semarang, Indonesia: Program Studi Ilmu Lingkungan Program Pasca Sarjana Universitas Diponegoro.

Ayunita, D. N., \& Hapsari, T. D. (2012). Analisis persepsi dan partisipasi masyarakat pesisir pada pengelolaan KKLD Ujungnegoro Kabupaten Batang. SEPA, 9(1), 117-124.

Basri. (2013). Penataan dan pengelolaan wilayah kelautan perspektif otonomi daerah dan pembangunan berkelanjutan. Perspektif, 18(3), 180-187.

Carlton, S. J., \& Jacobson, S. K. (2013). Climate change and coastal environmental risk perceptions in Florida. Journal of Environmental Management, 130, 32-39. doi: 10.1016/j.jenvman.2013.08.038.

Coastal \& Marine Union (EUCC). (2012). Measuring coastal sustainability. Retrieved from http://www.sustaineu.net/what_are_we_doing/measuring_coastal_sustainability.pdf.

Effendy, M. (2009). Pengelolaan wilayah pesisir secara terpadu: Solusi pemanfaatan ruang, pemanfaatan sumber daya dan pemanfaatan kapasitas asimilasi wilayah pesisir yang optimal dan berkelanjutan. Jurnal Kelautan, 2(1), 81-86. doi:10.21107/jk.v2i1.906.

Glaser, M., Christie, P., Diele, K., Dsikowitzky, L., Ferse, S., Nordhaus, I., . . . Wild, C. (2012). Measuring and understanding sustainability-enhancing processes in tropical coastal and marine social-ecological systems. Current Opinion in Environmental Sustainability, 4, 300-308. doi:10.1016/j.cosust.2012.05.004. 


\section{Studi Persepsi Masyarakat terhadap Tingkat Keberlanjutan Wilayah Pesisir Kecamatan Sarang}

Harris, J. M. (2000). Basic principles of sustainable development. Retrieved from http://www.ase.tufts.edu/gdae/publications/working_papers/Sustainable\%20Development.PDF.

Kay, R. C., \& Alder, J. (2005). Coastal planning and management. London: E\&F Spon.

Kumar, T. S., Mahendra, R. S., Nayak, S., Radhakrishnan, K., \& Sahu, K. C. (2010). Coastal vulnerability assessment for Orissa State, East Coast of India. Journal of Coastal Research, 26(3), 523-534. doi:10.2112/09-1186.1.

McGranahan, G., Balk, D., \& Anderson, B. (2007). The rising tide: Assessing the risks of climate change and human settelements in low elevation coastal zones. Environment and Urbanization, 19(1), 17-37. doi:10.1177/0956247807076960.

Ostrom, E. (2009). A general framework for analyzing sustainability of social-ecological systems. Science, 325, 419-422. doi:10.1126/science.1172133.

Ridwan, Y. H., \& Setiawan, R. P. (2013). Penilaian tingkat keberlanjutan pembangunan di Kabupaten Bangkalan sebagai daerah tertinggal. Teknik Pomits, 2(1), 1-5.

Rokhmin, D., \& Ginting, S. P. (2013). Pengelolaan sumber daya wilayah pesisir dan lautan secara terpadu. Jakarta: Balai Pustaka.

Sales Jr., R. F. M. (2009). Vulnerability and adaptation of coastal communities to climate variability and sealevel rise: Their implications for integrated coastal management in Cavite City, Philippines. Ocean \& Coastal Management, 52(7), 395-404. doi:10.1016/j.ocecoaman.2009.04.007.

Sugiyono. (2015). Metode Penelitian pendidikan (Pendekatan kuantitatif, kualitatif, dan R\&D). Bandung: CV. Alfabeta.

Suhadi. (2009). Cara Pandang dan perilaku masyarakat pesisir dalam menghadapi abrasi: Studi kasus pada kantong pemukiman sepanjang Pantai Sarang Rembang Jawa Tengah. Rembang: Dinas Pendidikan Kabupaten Rembang.

Sutrisno, S. (2015). Pemberdayaan dan partisipasi masyarakat pesisir dalam pengembangan tanaman mangrove di Kabupaten pati. Jurnal Bina Praja, 71), 63-73. doi:10.21787/jbp.07.2015.63-73.

Torresan, S., Critto, A., Valle, M. D., Harvey, N., \& Marcomini, A. (2008). Assessing coastal vulnerability to climate change: Comparing segmentation at global and regional scales. Sustainability Science, 3(1), 4565. doi:10.1007/s11625-008-0045-1.

Tuwo, A. (2011). Pengelolaan ekowisata pesisir dan laut: pendekatan ekologi, sosial-ekonomi, kelembagaan, dan sarana wilayah. Sidoarjo: Brilian Internasional. 